\title{
EFIKASI MIKROORGANISME LOKAL (MOL) SABUT KELAPA (Cocos nucifera L.) TERHADAP PERTUMBUHAN DAN PRODUKSI TANAMAN MENTIMUN (Cucumis sativus $\mathrm{L}$ )
}

\author{
Effication Of Coconut Fiber Local Microorganisms On The Growth And \\ Production Of Cucumber Plants (Cucumis sativus L)
}

\author{
Ahmad sidiq ${ }^{1,}$ Bagus Tripama ${ }^{2,}$ Insan wijaya ${ }^{3}$ \\ Program Studi Agroteknologi Fakultas Pertanian \\ Universitas Muhammadiyah Jember \\ 1Ahmadsidiqumj06@gmail.com² midastripama30@gmail.com \\ 3 insasnwijaya.jr@gmail.com
}

\begin{abstract}
ABSTRAK
Mentimun (Cucumis sativus L) merupakan merupakan salah satu jenis sayuran dari keluarga labu-labuan yang di sukai oleh seluruh lapisan masyarakat. Budidaya mentimun setiap tahun terus mengalami penurunan karena menurunnya kualitas tanah pertanian. Penggunaan Mikroorganisme Lokal (MOL) sabut kelapa menjadi salah satu alternatif untuk memperbaiki kualitas tanah. Penelitian ini bertujuan untuk mengetahui pengaruh berbagai konsentrasi mol sabut kelapa terhadap pertumbuhan dan produksi tanaman mentimun (Cucumis sfativus L.). penelitian dilaksanakan pada bulan Desember 2018 sampai Februari 2019 di Desa Kedungrejo, Kecamatan Rowokangkung, Kabupaten Lumajang. Rancangan yang digunakan Rancangan Acak Kelompok (RAK) Non Faktorial dengan 3 ulangan. Perlakuan terdiri dari 10 taraf yaitu S0 : tanpa mol, S1 : $10 \mathrm{~m} / 1, \mathrm{~S} 2: 20$ $\mathrm{ml} / \mathrm{l}, \mathrm{S} 3: 30 \mathrm{ml} / \mathrm{l}, \mathrm{S} 4: 40 \mathrm{ml} / \mathrm{l}, \mathrm{S} 5: 50 \mathrm{ml} / \mathrm{l}, \mathrm{S} 6: 60 \mathrm{ml} / \mathrm{l}, \mathrm{S} 7: \mathrm{ml} / \mathrm{l}, \mathrm{S} 8: 80 \mathrm{ml} / \mathrm{l}, \mathrm{S} 9: 90$ $\mathrm{ml} / \mathrm{l}$. Hasil penelitian menunjukkan bahwa perlakuan mol sabut kelapa memberikan pengaruh sangat nyata terhadap variabel pengamatan jumlah buah pertanaman, berat buah pertanaman, jumlah buah perplot, berat buah perplot. Berpengaruh nyata terhadap panjang buah, berat berangkasan basah, berat berangkasan kering. Berpengaruh tidak nyata terhadap tinggi tanaman 14 hts dan tinggi tanaman 21 hst. Secara keseluruhan perlakuan S3: $30 \mathrm{ml} / \mathrm{l}$ merupakan perlakuan terbaik.
\end{abstract}

Kata kunci : Mol, Mentimun, Konsentrasi

\begin{abstract}
Cucumber (Cucumis sativus L) is one type of vegetable from the pumpkin family that is loved by all levels of society. Cucumber cultivation continues to decline every year due to declining quality of agricultural land. The use of local microorganisms coconut fiber is one alternative to improve soil quality. This study aims to determine the effect of various concentrations of local coir coconuts on the growth and production of cucumber plants (Cucumis sativus L). The study was conducted in December 2018 to February 2019 in Kedungrejo Village, Rowokangkung District, Lumajang Regency. The design of the Non Factorial Randomized Group design with one factor was repeated 3 times, The treatment consists of 10 levels that is : S0: without $\mathrm{mol},: 10 \mathrm{~m} / \mathrm{l}, \mathrm{S} 2: 20 \mathrm{ml} / \mathrm{l}, \mathrm{S3}: 30 \mathrm{ml} / \mathrm{l}, \mathrm{S4}: 40$ $\mathrm{ml} / \mathrm{l}, \mathrm{S} 5: 50 \mathrm{ml} / \mathrm{l}, \mathrm{S6}: 60 \mathrm{ml} / \mathrm{l}, \mathrm{S} 7: \mathrm{ml} / \mathrm{l}, \mathrm{S8}: 80 \mathrm{ml} / \mathrm{l}, \mathrm{S9}: 90 \mathrm{ml} / \mathrm{l}$. The results showed that the treatment of coconut husk moles gave a very significant influence on the observation variables of the number of fruit crops, weight of fruit crops, number of fruits per plot, perplot fruit weight. Significantly affect fruit length, wet wet weight, dry wet weight. Not significant effect on plant height 14 hts and plant height 21 hst. Overall, the $S 3: 30 \mathrm{ml} / \mathrm{l}$ treatment was the best treatment.
\end{abstract}

Keywords: Mol, Cucumber, concentrations 


\section{PENDAHULUAN}

Mentimun termasuk salah satu jenis sayuran buah yang memiliki banyak manfaat dalam kehidupan masyarakat sehari - hari, sehingga permintaan terhadap komoditi ini sangat besar. Buah ini disukai oleh seluruh golongan masyarakat yang berpenghasilan rendah sampai berpenghasilan tinggi, sehingga buah mentimun dibutuhkan dalam jumlah relatif dan berkesinambungan. Kebutuhan buah mentimun cenderung terus meningkat sejalan dengan pertambahan penduduk, peningkatan taraf hidup, tingkat pendidikan, dan kesadaran masyarakat tentang pentingnya nilai gizi (Cahyono, 2003).

Mentimun termasuk golongan sayuran buah seperti labu siam, paria, oyong, beligodan semangka. Orang menggemari mentimun karena rasanya enak, segar dan dingin. Kandungan nutrisi per $100 \mathrm{~g}$ mentimun terdiri dari 15 kalori, 0,8 $\mathrm{g}$ protein, $3 \mathrm{~g}$ karbohidrat, $30 \mathrm{mg}$ fosfor, $0,5 \mathrm{mg}$ besi, 0,02 thianine, $0,01 \mathrm{mg}$ riboflan, $14 \mathrm{mg}$ asam, 0,3 $\mathrm{mg}$ vitamin A,0,3 $\mathrm{mg}$ vitamin B1, 0,02 $\mathrm{mg}$ vitamin Bdan 8,0 mg vitamin C (Sumpena, 2005).

Produksi mentimun secara nasional terus mengalami penurunan dalam kurun waktu tertentu, produksi mentimun pada tahun 2009 berproduksi 540.122 ton, pada tahun 2010 berproduksi 583.149 ton, pada tahun 2011 berproduksi 547.14 ton, pada tahun 2012 berproduksi 511.525 ton. Sementara kebutuhan akan mentimun terus meningkat seiring dengan kesadaran masyarakat untuk mengkonsumsi sayuran (BPS RI, 2014).

Salah satu faktor penting untuk meningkatkat pertumbuhan dan produksi tanaman mentimun adalah pemupukan. Pemupukan menggunakan mikroorganisme lokal adalah cara untuk memberikan unsur hara bagi tanaman agar pertumbuhan dan produksinya optimal. Menurut (Purwasasmita, 2009), Larutan MOL (Mikroorganisme Lokal) adalah larutan hasil fermentasi yang berbahan dasar dari berbagai sumberdaya yang tersedia setempat. Larutan MOL mengandung unsur hara mikro dan makro dan juga mengandung bakteri yang berpotensi sebagai perombak bahan organik, perangsang pertumbuhan, dan sebagai agensia pengendali hama dan penyakit tanaman, sehingga MOL dapat digunakan baik sebagai dekomposer, pupuk hayati, dan sebagai pestisida organik terutama sebagai fungisida.

Sabut kelapa merupakan limbah pengolahan kelapa yang dapat diolah menjadi mol. Sabut kelapa bisa digunakan sebagai bahan untuk pembuatan pupuk organik cair, karena didalam sabut kelapa terdapat unsur hara makro dan mikro. Kandungan unsur hara yang terdapat dalam sabut kelapa, yaitu: air 53,83\%, N 0,28\%, P 0,1 ppm, K 6,726 ppm, Ca 140 ppm, dan Mg 170 ppm (Prawoso, 2001 dalam Jamilah, Napitupulu dan Marni, 2013).

Penelitian ini bertujuan untuk untuk mengetahui pengaruh konsentrasi Mikroorganisme Lokal (MOL) Sabut Kelapa (Cocos nucifera L.) terhadap pertumbuhan Tanaman Mentimun (Cucumis sativus L) dan Untuk mengetahui 
pengaruh konsentrasi Mikroorganisme Lokal (MOL) Sabut Kelapa (Cocos nucifera L.) terhadap produksi Tanaman Mentimun (Cucumis satipus L)

\section{METODE PENELITIAN}

Penelitian ini dilaksanakan di Desa Kedungrejo, Kecamatan Rowokangkung, Kabupaten Lumajang dengan ketinggian tempat $+60 \mathrm{mdpl}$, dengan suhu berkisar $(24-31)^{0}$ C. Dimulai pada bulan Desember 2018 sampai bulan Maret 2019. Rancangan yang digunakan adalah Rancangan Acak Kelompok (RAK) Nonfaktorial yaitu mol sabut kelapa (S) yang diulang 3 kali S0 : tanpa MOL, S1 : Pemberian MOL dengan konsentrasi $10 \mathrm{ml} / \mathrm{l}, \mathrm{S} 2$ : Pemberian MOL dengan konsentrasi 20 ml/l, S3 : Pemberian MOL dengan konsentrasi $30 \mathrm{ml} / \mathrm{l}, \mathrm{S} 4$ : Pemberian MOL dengan konsentrasi $40 \mathrm{ml} / \mathrm{l}$, S5 : Pemberian MOL dengan konsentrasi $50 \mathrm{ml} / \mathrm{l}$, S6 : Pemberian MOL dengan konsentrasi $60 \mathrm{ml} / \mathrm{l}, \mathrm{S} 7$ : Pemberian MOL dengan konsentrasi $70 \mathrm{ml} / \mathrm{l}$, S8 : Pemberian MOL dengan konsentrasi $80 \mathrm{ml} / \mathrm{l}$, S9 : Pemberian MOL dengan konsentrasi $90 \mathrm{ml} / \mathrm{l}$. Variabel pengamatan sebagai berikut: (1) Tinggi Tanaman(cm) HST, Pengamatan tinggi tanaman dilakukan pada saat tanaman berumur 14 dan 21 hari setelah tanam (hst). Tinggi tanaman diukur dengan menggunakan penggaris mulai dari leher akar sampai titik tumbuh terakhir. (2) Jumlah Buah Per Tanaman (buah) HST, Menghitung jumlah buah total yang di panen pada tanaman sampel sampai panen terakhir. (3) Jumlah Buah Per Plot (buah) HST, Menghitung jumlah buah total perplot yang dilakukan pada setiap panen sampai panen terakhir. (4) Berat Buah Per Tanaman (gram) HST, Menimbang Berat buah total yang di panen pada tanaman sampel menggunakan timbangan digital sampai panen terakhir. (5) Berat Buah Per Plot (gram) HST, Menimbang Berat buah total perplot menggunakan timbangan digital yang dilakukan sampai panen terakhir. (6) Panjang Buah (cm), Mengukur Panjang buah diukur dengan menggunakan penggaris dari ujung buah sampai pangkal buah. (7) Berat Berangkasan Basah (g), Menimbang berat basah tanaman yang dilakukan setelah panen berakhir. Tanaman dicabut dan segera ditimbang. (8) Berat Berangkasan Kering (g), Menimbang berat total brangkasan tanaman dalam kondisi kering setelah air dalam jaringan dihilangkan. Penurunan kadar air dilakukan dijemur dibawah terik matahari sampai berat akhirnya konstan.

\section{HASIL DAN PEMBAHASAN}

Tabel 1 .Rangkuman hasil analisis ragam terhadap semua variabel pengamatan.

\begin{tabular}{|c|c|c|c|}
\hline No & Variabel pengamatan & F-hitung & \\
\hline 1 & Tinggi Tanaman 14 hst & 1,21 & ns \\
\hline 2 & Tinggi Tanaman $21 \mathrm{hst}$ & 0,65 & ns \\
\hline 3 & Jumlah Buah Per Tanaman & 18,49 & $* *$ \\
\hline 4 & Berat Buah Per Tanaman & 5,41 & $* *$ \\
\hline
\end{tabular}




\begin{tabular}{llrl}
\hline 5 & Jumlah Buah Per Plot & 18,49 & $* *$ \\
6 & Berat Buah Per Plot & 5,41 & $* *$ \\
7 & Panjang Buah & 2,51 & $*$ \\
8 & Berat Berangkasan Basah & 2,56 & $*$ \\
9 & Berat Berangkasan Kering & 2,74 & $*$ \\
\hline
\end{tabular}

Keteranganan : ns : tidak berbeda nyata; $*$ : berbeda nyata; $* *$ : berbeda sangat nyata

\section{Tinggi Tanaman}

Berdasarkan Tabel 1, hasil analisis ragam menunjukkan bahwa pengaplikasian mol sabut kelapa tidak berbeda nyata pada variable pengamatan tinggi tanaman (14 dan 21) hst. Tinggi tanaman dapat dilihat pada gambar 1.

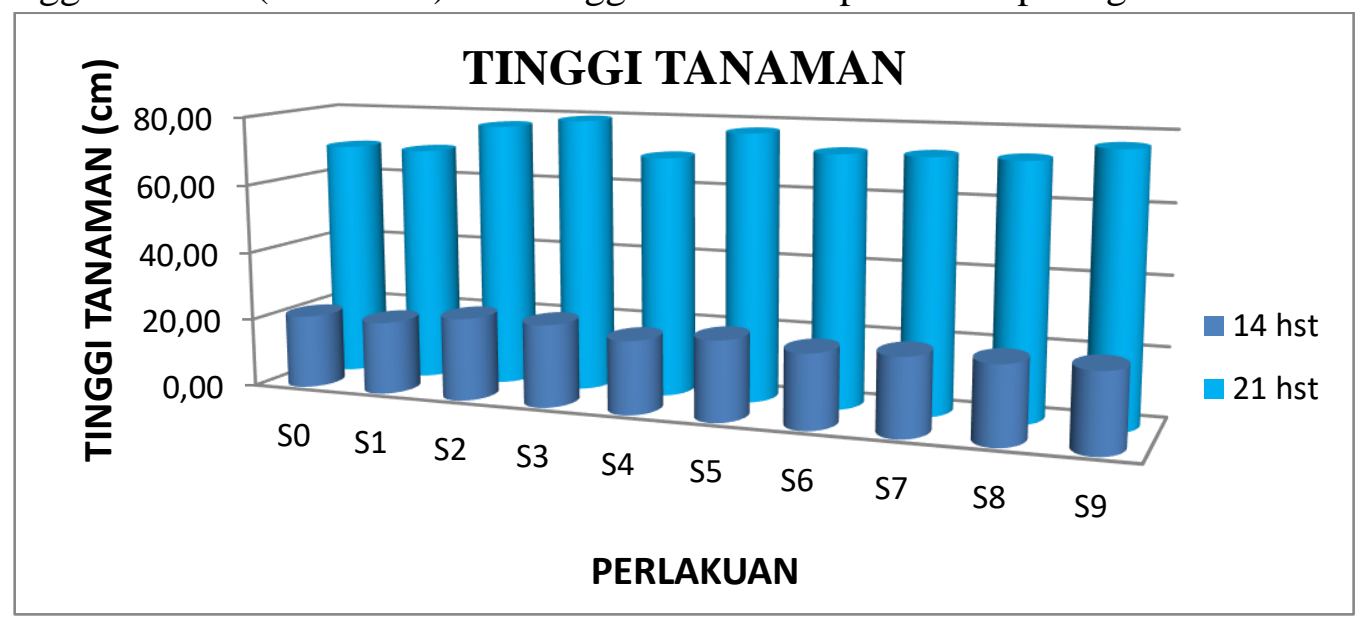

Gambar 1. Pengaruh Mol Sabut Kelapa terhadap Tinggi tanamanumur (14 dan 21) hst

Berdasarkan gambar 1. Dapat dijelaskan tinggi tanaman 14 hst perlakuan tertinggi S3 (Pemberian MOL Sabut Kelapa konsentrasi $30 \mathrm{ml} / \mathrm{l}$ ) yaitu tinggi tanaman $23,83 \mathrm{~cm}$. Perlakuan terendah S0 (tanpa pemberian MOL/Kontrol) yaitu tinggi tanaman $21,23 \mathrm{~cm}$. Tinggi tanaman 21 hst perlakuan tertinggi S3 (Pemberian MOL Sabut Kelapa konsentrasi $30 \mathrm{ml} / \mathrm{l}$ ) yaitu tinggi tanaman 79,21 $\mathrm{cm}$. Perlakuan terendah S0 (tanpa pemberian MOL/Kontrol) yaitu tinggi tanaman $69,18 \mathrm{~cm}$.

Pengaruh mol sabut kelapa berpengaruh tidak nyata terhadap variable pengamatan tinggi tanaman pada umur (14,dan 21) hst. Hal ini diduga Mol sabut kelapa mengandung bakteri pelarut fosfat salah satunya adalah Pseudomonas. Menurut Nursanti, I. (2017), Beberapa peneliti mengemukakan bahwa bakteri yang hidup di permukaan akar seperti Pseudomonas fluorescens, $P$ putida dan $P$. Striata. Bakteri tersebut dapat menghasilkan zat pengatur tumbuh seperti asam indol asetat (IAA) dan asam giberelin (GA3).

Giberelin selain menambah tinggi tanaman juga menambah luas daun dan berat kering tanaman, dan pertambahan berat kering merupakan hasil peningkatan aktifitas fotosintesis (Surachmat, 1984). Fungsi hormon IAA bagi tanaman antara lain meningkatkan perkembangan sel, merangsang pembentukan 
akar baru, memacu pertumbuhan, merangsang pembungaan dan meningkatkan aktivitas enzim (Rahni, 2012).

Pengaplikasi mikroorganisme lokal tidak memberi pengaruh yang signifikan terhadap tinggi tanaman karena mikroba membutuhkan waktu untuk menyediakan unsur hara, Sehingga perlakuan dari mol sabut kelapa tidak berbeda nyata terhadap parameter pengamatan tinggi tanaman. Menurut handayani $d k k$, (2015). Unsur hara yang terkandung didalam MOL umumnya dalam jumlah sedikit akan tetapi, proses pemenuhan kebutuhan hara tanaman dengan pemberian MOL dapat dipenuhi dari efektivitas mikroba yang terkandung di dalam MOL untuk merombak bahan organik yang tersedia di dalam tanah.

\section{Jumlah Buah Per Tanaman}

Berdasarkan tabel 1, hasil analisis ragam menunjukkan bahwa pengaruh pengaplikasian mol berpengaruh sangat nyata terhadap variabel pengamatan jumlah buah per tanaman.

Tabel 2. Pengaruh mol sabut kelapa terhadap jumlah buah pertanaman.

$\begin{array}{cc}\text { PERLAKUAN } & \begin{array}{c}\text { Rata-Rata Jumlah } \\ \text { Buah Per Tanaman }\end{array}\end{array}$

S3 ( Pemberian MOL Sabut Kelapa konsentrasi $30 \mathrm{ml} / \mathrm{l}$ )

17 a

S5 ( Pemberian MOL Sabut Kelapa konsentrasi $50 \mathrm{ml} / \mathrm{l}) \quad 14$ b

S6 ( Pemberian MOL Sabut Kelapa konsentrasi $60 \mathrm{ml} / \mathrm{l}) \quad 14$ b

S2 ( Pemberian MOL Sabut Kelapa konsentrasi $20 \mathrm{ml} / \mathrm{l}$ ) 14 b

S4 ( Pemberian MOL Sabut Kelapa konsentrasi $40 \mathrm{ml} / \mathrm{l}) \quad 13$ b

S9 ( Pemberian MOL Sabut Kelapa konsentrasi $90 \mathrm{ml} / \mathrm{l}) \quad 12$ bc

S1 ( Pemberian MOL Sabut Kelapa konsentrasi $10 \mathrm{ml} / \mathrm{l}$ ) 12 bc

S7 ( Pemberian MOL Sabut Kelapa konsentrasi $70 \mathrm{ml} / \mathrm{l}) \quad 12$ bc

S8 ( Pemberian MOL Sabut Kelapa konsentrasi $80 \mathrm{ml} / \mathrm{l}) \quad 12$ bc

S0 ( tanpa pemberian MOL)

$10 \mathrm{c}$

Keterangan : Angka-angka yang diikuti huruf yang sama menunjukkan berbeda tidak nyata pada Uji jarak berganda Duncan taraf $5 \%$

Berdasarkan uji DMRT 5\%, dapat dijelaskan bahwa perlakuan S3 (Pemberian MOL Sabut Kelapa konsentrasi $30 \mathrm{ml} / \mathrm{l}$ ) berbeda nyata dengan perlakuan S5 (Pemberian MOL Sabut Kelapa konsentrasi $50 \mathrm{ml} / \mathrm{l}$ ), dan perlakuan S0 (tanpa pemberian MOL). Sedngkan perlakuan S5 (Pemberian MOL Sabut Kelapa konsentrasi $50 \mathrm{ml} / \mathrm{l}$ ) tidak berpengaruh nyata terhadap perlakuan yang lain. Perlakuan S3 (Pemberian MOL Sabut Kelapa konsentrasi $30 \mathrm{ml} / \mathrm{l}$ ) menghasilkan rata-rata terbaik pada jumlah buah per tanaman yaitu 17 buah.

Mol sabut kalapa mengandung unsur hara kalium dan mikroba pelarut phosphat yang dapat merombat bahan organik dalam tanah dan menghasilkan unsur hara P yang dapat langsung diserap tanaman .Menurut Galla, E. A. (2018). Unsur $\mathrm{P}$ dan $\mathrm{K}$ sangat berpengaruh terhadap berat buah karena berperan dalam proses metabolisme, pembentunan jaringan penyimpanan, pembentukan protein dan karbohidrat, serta meningkatkan kualitas buah. 


\section{Berat Buah Per Tanaman}

Berdasarkan tabel 1, hasil analisis ragam menunjukkan bahwa pengaruh pengaplikasian mol berpengaruh sangat nyata terhadap variabel pengamatan berat buah per tanaman.

Tabel 3. Pengaruh mol sabut kelapa terhadap berat buah pertanaman.

\begin{tabular}{lrl}
\hline PERLAKUAN & $\begin{array}{c}\text { Rata-Rata Berat Buah } \\
\text { Per Tanaman }(\mathbf{g})\end{array}$ \\
\hline S3 ( Pemberian MOL Sabut Kelapa konsentrasi 30 ml/l) & 6747,00 & $\mathrm{a}$ \\
S2 ( Pemberian MOL Sabut Kelapa konsentrasi 20 ml/l) & 5363,44 & $\mathrm{~b}$ \\
S6 ( Pemberian MOL Sabut Kelapa konsentrasi 60 ml/l) & 5348,67 & $\mathrm{~b}$ \\
S4 ( Pemberian MOL Sabut Kelapa konsentrasi 40 ml/l) & 5169,94 & $\mathrm{~b}$ \\
S5 ( Pemberian MOL Sabut Kelapa konsentrasi $50 \mathrm{ml} / \mathrm{l})$ & 5124,56 & $\mathrm{~b}$ \\
S8 ( Pemberian MOL Sabut Kelapa konsentrasi $80 \mathrm{ml} / \mathrm{l})$ & 4809,61 & $\mathrm{~b}$ \\
S1 ( Pemberian MOL Sabut Kelapa konsentrasi $10 \mathrm{ml} / \mathrm{l})$ & 4594,00 & $\mathrm{bc}$ \\
S9 ( Pemberian MOL Sabut Kelapa konsentrasi $90 \mathrm{ml} / \mathrm{l})$ & 4581,44 & $\mathrm{bc}$ \\
S7 ( Pemberian MOL Sabut Kelapa konsentrasi 70 ml/l) & $4440,06 \mathrm{bc}$ \\
S0 ( tanpa pemberian MOL) & $3583,33 \quad \mathrm{c}$ \\
\hline
\end{tabular}

Keterangan : Angka-angka yang diikuti huruf yang sama menunjukkan berbeda tidak nyata pada Uji jarak berganda Duncan taraf $5 \%$

Berdasarkan uji DMRT 5\%, dapat dijelaskan bahwa perlakuan S3 (Pemberian MOL Sabut Kelapa konsentrasi $30 \mathrm{ml} / \mathrm{l}$ ) berbeda nyata dengan perlakuan S2 (Pemberian MOL Sabut Kelapa konsentrasi $20 \mathrm{ml} / \mathrm{l}$ ) dan S0 (tanpa pemberian MOL) sedangkan perlakuan S2 (Pemberian MOL Sabut Kelapa konsentrasi $20 \mathrm{ml} / \mathrm{l}$ ) tidak berbeda nyata dengan perlakuan yan lain. Perlakuan S3 (Pemberian MOL Sabut Kelapa konsentrasi $30 \mathrm{ml} / \mathrm{l}$ ) menghasilkan rata-rata terbaik pada berat buah per tanaman yaitu 6747 gram. Hal ini diduga terdapat bakteri pseudomonas sp. yang terkandung dalam mol sabut kalapa.

Bakteri pseudomonas sp. Merupakan bakteri yang dapat menfiksasi unsur hara fosfor didalam tanah sehingga dapat meningkatkan bobot buah mentimun. Merujuk dari hasil penelitian fitriatin (2009), mengemukakan bahwa bakteri pseudomonas sp.dan fungi penicillium sp. Bekerja secara sinergis mengeluarkan enzim fosfatase dalam proses mineralisasi dan immobilisasi untuk mengubah $\mathrm{P}$ organik menjadi $\mathrm{P}$ anorganik. Kesinergisan tersebut membantu menyediakan $\mathrm{P}$ bagi tanaman padi gogo sehingga pengisian bulir-bulir padi dapat meningkat.

\section{Jumlah Buah Per Plot}

Berdasarkan tabel 1, hasil analisis ragam menunjukkan bahwa pengaruh pengaplikasian mol berpengaruh sangat nyata terhadap variabel pengamatan jumlah buah per plot.

Berdasarkan uji DMRT 5\%, dapat dijelaskan bahwa perlakuan S3 (Pemberian MOL dengan konsentrasi $30 \mathrm{ml} / \mathrm{l}$ ) berbeda nyata dengan perlakuan S5 (Pemberian MOL dengan konsentrasi $50 \mathrm{ml} / \mathrm{l}$ ) dan perlakuan S0 (tanpa pemberian MOL). Perlakuan S3 (Pemberian MOL dengan konsentrasi $30 \mathrm{ml} / \mathrm{l}$ ) menghasilkan rata-rata terbaik pada jumlah buah per plot yaitu 100 buah. Hal ini 
diduga mol sabut kelapa mengandung bakteri pelarut fosfat dan unsur hara kalium.

Tabel 4. Pengaruh mol sabut kelapa terhadap jumlah buah per plot.

\begin{tabular}{lr}
\hline \multirow{2}{*}{ Perlakuan } & Rata-rata Jumlah Buah Per \\
Plot
\end{tabular}

Keterangan : Angka-angka yang diikuti huruf yang sama menunjukkan berbeda tidak nyata pada Uji jarak berganda Duncan taraf 5\%

Jumlah buah berhubungan erta dengan jumlah bunga yang terbentuk menjaadi buah. salah satu hara yang berperan penting terhadap pembentunkan bengan adalah kalium. Mol Sabut kelapa mengandung kalium sebesar 0,063\% Menurut Marschner (Martias 2011) kalium berfungsi sebagai katalisator untuk pembentukan karbohidrat dalam proses fotosintesis, pembentukan protein, translokasi gula dan protein, membantu dalam proses membuka dan menutupnya stomata, meningkatkan efisiensi penggunaan air, memperluas pertumbuhan akar, memperkuat jaringan dan organ-organ tanaman sehingga tidak mudah rontok, meningkatkan daya tahan tanaman terhadap serangan hama, serta meningkatkan kualitas dan kuantitas buah.

Hasil penelitian ini menunjukan bahwa masa panen Tanaman mentimun pada umur 32 hst sudah layak untuk dipanen, panen dilakukan setiap 2 hari sekali sampai umur 56 hst (panen ke 13). Panen ke 1 sampai panen ke 13 menunjukkan jumlah buah yang berbeda. Jumlah per panen dapat dilihat pada gambar 2 .

Berdasarkan gambar 2. Dapat dijelaskan bahwa jumlah buah setiap panen mengalami pertambahan jumlah buah dan jumlah buah tertinggi pada panen ke 6 (42 hst) pada perlakuan S3 ( Pemberian MOL dengan konsentrasi $30 \mathrm{ml} / \mathrm{l}$ ) yaitu 48 buah. panen pertama menghasilkan 2 buah, panen kedua meningkat siknifikan yaitu 12 buah. pada perlakuan S5 ( Pemberian MOL dengan konsentrasi $50 \mathrm{ml} / \mathrm{l}$ ) panen pertama menghasilkan 4 buah, panen kedua meningkat siknifikan yaitu 18 buah dan puncak panen terjadi pada panen ke 6 (42 hst) yaitu 38 buah serta puncak panen ke dua terjadi pada panen ke 10 (50 hst) yaitu 42 buah. pada perlakuan S9 ( Pemberian MOL dengan konsentrasi $90 \mathrm{ml} / \mathrm{l}$ ) panen pertama menghasilkan 5 buah dan puncak panen terjadi pada panen ke 6 (42 hst) yaitu 34 buah serta puncak panen ke dua terjadi pada panen ke 10 (50 hst) yaitu 47 buah. 


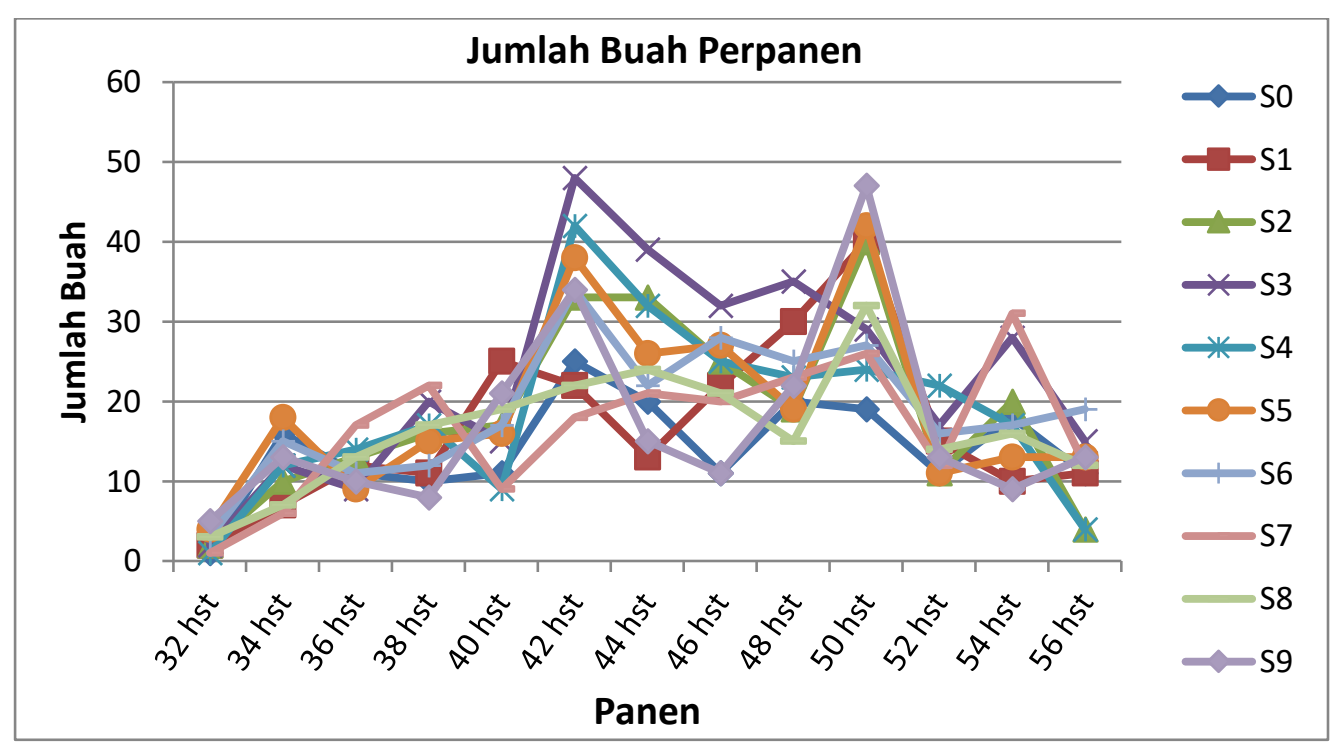

Gambar 2. Pengaruh Mol Sabut Kelapa terhadap Jumlah buah per panen

\section{Berat Buah Per Plot}

Berdasarkan tabel 1, hasil analisis ragam menunjukkan bahwa pengaruh pengaplikasian mol berpengaruh sangat nyata terhadap variabel pengamatan berat buah per plot.

Tabel 5. Pengaruh mol sabut kelapa terhadap berat total buah per plot tanaman mentimun.

\section{Perlakuan}

Rata-rata Berat Buah

S3 ( Pemberian MOL dengan konsentrasi $30 \mathrm{ml} / \mathrm{l}$ )

S2 ( Pemberian MOL dengan konsentrasi $20 \mathrm{ml} / \mathrm{l}$ )

S6 ( Pemberian MOL dengan konsentrasi $60 \mathrm{ml} / \mathrm{l}$ )

S4 ( Pemberian MOL dengan konsentrasi $50 \mathrm{ml} / \mathrm{l}$ )

S5 ( Pemberian MOL dengan konsentrasi $50 \mathrm{ml} / \mathrm{l}$ )

S8 ( Pemberian MOL dengan konsentrasi $80 \mathrm{ml} / \mathrm{l}$ )

S1 ( Pemberian MOL dengan konsentrasi $10 \mathrm{ml} / \mathrm{l}$ )

S9 ( Pemberian MOL dengan konsentrasi 90 ml/l)

S7 ( Pemberian MOL dengan konsentrasi $70 \mathrm{ml} / \mathrm{l}$ )

S0 ( tanpa pemberian MOL)
Per Plot (gram)

40482,00 a

$32180,67 \quad b$

$32092,00 \quad b$

$31019,67 \quad b$

30747,33 b

$28857,67 \quad b$

27564,00 bc

27488,67 bc

26640,33 bc

21500,00 c

Keterangan : Angka-angka yang diikuti huruf yang sama menunjukkan berbeda tidak nyata pada Uji jarak berganda Duncan taraf 5\%

Berdasarkan uji DMRT 5\%, dapat dijelaskan bahwa perlakuan S3 (Pemberian MOL dengan konsentrasi $30 \mathrm{ml} / \mathrm{l}$ ) berbeda nyata dengan perlakuan S2 (Pemberian MOL dengan konsentrasi $20 \mathrm{ml} / \mathrm{l}$ ) dan S0 (tanpa pemberian MOL). Perlakuan S3 (Pemberian MOL dengan konsentrasi $30 \mathrm{ml} / \mathrm{l}$ ) menghasilkan ratarata terbaik pada berat buah per plot yaitu 40482 gram. Hal ini diduga bakteri mol sabut kelapa berfungsi sebagai pelarut uunsur P. Menurut Galla, E. A. (2018). unsur $\mathrm{P}$ yang berperan penting dalam pembelahan sel, perkembangan jaringan meristem, pertumbuhan jaringan, mempercepat pembungaan dan pemasakan buah, sehingga dengan adanya kandungan $\mathrm{P}$ dalam pupuk tersebut akan 
mempengaruhi terbentuknya cabang produktif yang menghasilkan bunga lalu buah.

Di dalam sabut kelapa terkandung unsur-unsur hara dari alam yang sangat dibutuhkan tanaman yaitu kalium (K) (wijaya ,2017). Mol Sabut kelapa mengandung unsur hara kalium $\left(\mathrm{K}_{2} \mathrm{O}\right)$ sebesar 0,063\%. Mol Sabut kelapa yang mengandung unsur $\mathrm{K}$ tersebut sangat baik jika diberikan sebagai pupuk cair serta pengganti pupuk $\mathrm{KCl}$ anorganik untuk tanaman.

Gardner et al. (1991) bahwa kalium dapat memperkuat jaringan dan organ-organ tanaman sehingga tidak mudah rontok, serta meningkatkan translokasi hasil fotosintesis ke dalam floem. Oleh karena itu dapat menyebabkan jumlah buah, bobot per buah, dan bobot buah per tanaman mentimun menjadi lebih tinggi. Berat per panen dapat dilihat pada gambar 3.

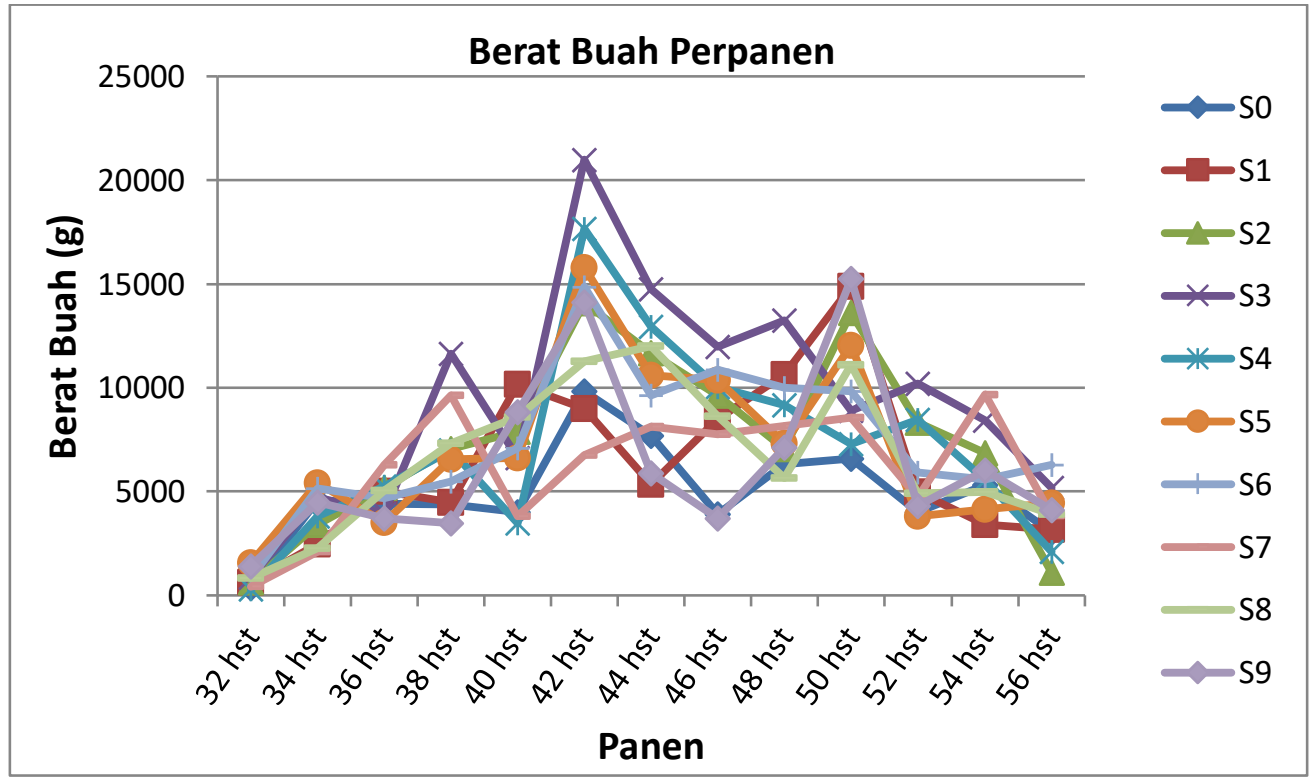

Gambar 3. Pengaruh Mol Sabut Kelapa terhadap Berat total buah per panen

Berdasarkan gambar 3. Dapat dijelaskan bahwa berat buah total tertinggi pada panen ke 6 (42 hst) pada perlakuan S3 (Pemberian MOL dengan konsentrasi $30 \mathrm{ml} / \mathrm{l}) 20990$ gram $(20,99 \mathrm{~kg}$ ). Pada perlakuan S4 (Pemberian MOL dengan konsentrasi $40 \mathrm{ml} / \mathrm{l})$ puncak panen terjadi pada panen ke 6 (42 hst) yaitu 17662 gram $(17,66 \mathrm{~kg}$ ). Pada perlakuan S9 (Pemberian MOL dengan konsentrasi 90 $\mathrm{ml} / \mathrm{l})$ puncak panen terjadi pada panen ke 6 (42 hst) yaitu 14132 gram $(14,13 \mathrm{~kg})$ dan puncak panen kedua terjadi pada panen ke $10(50 \mathrm{hst})$ yaitu $15.241(15,24 \mathrm{~kg})$

\section{Panjang Buah Per Plot}

Berdasarkan tabel 1, hasil analisis ragam menunjukkan bahwa pengaruh pengaplikasian mol berpengaruh sangat nyata terhadap variabel pengamatan panjang buah per plot. 
Tabel 6. Pengaruh mol sabut kelapa terhadap panjang buah per plot tanaman mentimun.

\begin{tabular}{cc} 
Perlakuan & $\begin{array}{c}\text { Rata-rata Panjang Buah } \\
\text { Per Plot (cm) }\end{array}$ \\
\hline S3 ( Pemberian MOL dengan konsentrasi 30 ml/l) & $23,66 \quad \mathrm{a}$ \\
S2 ( Pemberian MOL dengan konsentrasi $20 \mathrm{ml} / \mathrm{l})$ & $23,56 \quad \mathrm{ab}$ \\
S6 ( Pemberian MOL dengan konsentrasi $60 \mathrm{ml} / \mathrm{l})$ & $23,55 \mathrm{ab}$ \\
S4 ( Pemberian MOL dengan konsentrasi $40 \mathrm{ml} / \mathrm{l})$ & $23,53 \mathrm{ab}$ \\
S5 ( Pemberian MOL dengan konsentrasi $50 \mathrm{ml} / \mathrm{l})$ & $23,40 \mathrm{abc}$ \\
S7 ( Pemberian MOL dengan konsentrasi 70 ml/l) & $23,37 \mathrm{abc}$ \\
S8 ( Pemberian MOL dengan konsentrasi $80 \mathrm{ml} / \mathrm{l})$ & $23,26 \mathrm{abc}$ \\
S9 ( Pemberian MOL dengan konsentrasi $90 \mathrm{ml} / \mathrm{l})$ & $23,26 \mathrm{abc}$ \\
S1 ( Pemberian MOL dengan konsentrasi $10 \mathrm{ml} / \mathrm{l})$ & $23,19 \mathrm{bc}$ \\
S0 ( tanpa pemberian MOL) & $23,02 \mathrm{c}$ \\
\hline Keterangan : Angka-angka yang diikuti huruf yang sama menunjukkan berbeda tidak nyata pada \\
Uji jarak berganda Duncan taraf 5\%
\end{tabular}

Berdasarkan uji DMRT 5\%, dapat dijelaskan bahwa perlakuan S3 (Pemberian MOL dengan konsentrasi $30 \mathrm{ml} / \mathrm{l}$ ) tidak berbeda nyata dengan variabel perlakuan S2 (Pemberian MOL dengan konsentrasi $20 \mathrm{ml} / \mathrm{l}$ ) tetapi berbeda nyata dengan variabel perlakuan S1 (Pemberian MOL dengan konsentrasi $10 \mathrm{ml} / \mathrm{l}$ ) dan S0 (tanpa pemberian MOL). Perlakuan yang menghasilkan rata-rata tertinggi yaitu S3 (Pemberian MOL dengan konsentrasi $30 \mathrm{ml} / \mathrm{l}$ ) dengan pangjang buah 23,66 cm. Hal ini diduga pengaruh dari unsur forfor yang dihasilkan oleh mikroba pelarut phosphat (Bacillus circularis, Bacillus megaterium, dan Bacillus Firmus ) yang terkandung dalam mol sabut kelapa.

Menurut Firdausi, (2016). Genus Bacillus mempunyai kemampuan untuk mengubah fosfat tidak larut menjadi bentuk tersedia untuk tanaman dengan mengeluarkan asam organik. Asam organik mampu untuk menurunkan $\mathrm{pH}$ dan mampu melarutkan fosfat yang terikat dengan kation tanah berupa $\mathrm{Al}, \mathrm{Fe}, \mathrm{Ca}$ dan Mg lalu mengubahnya menjadi bentuk tersedia untuk tanaman

Unsur Fosfor berperan dalam membantu perkembangan akar muda, dimana akar tanaman yang subur dapat memperkuat berdirinya tanaman dan dapat meningkatkan penyerapan unsur hara yang dibutuhkan tanaman sedangakan Kalium memberikan pengaruh terhadap pertumbuhan tanaman ke atas dan pembentukan kuncup serta diperlukan dalam pemanjangan sel-sel, sintesis dan pembelahan sel (Norhasanah, 2011).

\section{Berat Brangkasan Basah}

Berdasarkan tabel 1, hasil analisis ragam menunjukkan bahwa pengaruh pengaplikasian mol berpengaruh nyata terhadap variabel pengamatan berat brangkasan basah.

Berdasarkan uji DMRT 5\%, dapat dijelaskan bahwa perlakuan S3 (Pemberian MOL dengan konsentrasi $30 \mathrm{ml} / \mathrm{l}$ ) tidak berbeda nyata dengan variabel perlakuan S4 (Pemberian MOL dengan konsentrasi $40 \mathrm{ml} / \mathrm{l}$ ) tetapi berbeda nyata dengan variabel perlakuan S7 (Pemberian MOL dengan konsentrasi $70 \mathrm{ml} / \mathrm{l}$ ) dan S0 (tanpa pemberian MOL). Perlakuana yang menghasilkan rata-rata 
tertinggi yaitu S3 (Pemberian MOL dengan konsentrasi $30 \mathrm{ml} / \mathrm{l}$ ) dengan berat brangkasan basah 871,22 gram. Hal ini diduga bakeri pelarut phosphat menyediakan hara fosfor.

Tabel 7. Pengaruh mol sabut kelapa terhadap berat brangkasan basah tanaman mentimun.

\begin{tabular}{|c|c|}
\hline perlakuan & $\begin{array}{c}\text { Rata-rata Berat } \\
\text { Berangkasan Basah }(\mathrm{g})\end{array}$ \\
\hline S3 ( Pemberian MOL dengan konsentrasi $30 \mathrm{ml} / \mathrm{l}$ ) & $871,22 \quad \mathrm{a}$ \\
\hline S4 ( Pemberian MOL dengan konsentrasi $40 \mathrm{ml} / \mathrm{l}$ ) & 817,33 \\
\hline S2 ( Pemberian MOL dengan konsentrasi $20 \mathrm{ml} / \mathrm{l})$ & 791,67 \\
\hline S5 ( Pemberian MOL dengan konsentrasi $50 \mathrm{ml} / \mathrm{l}$ ) & 775,94 \\
\hline S6 ( Pemberian MOL dengan konsentrasi $60 \mathrm{ml} / \mathrm{l}$ ) & 735,39 \\
\hline S7 ( Pemberian MOL dengan konsentrasi $70 \mathrm{ml} / \mathrm{l}$ ) & 709,39 \\
\hline S1 ( Pemberian MOL dengan konsentrasi $10 \mathrm{ml} / \mathrm{l}$ ) & 706,78 \\
\hline S8 ( Pemberian MOL dengan konsentrasi $80 \mathrm{ml} / \mathrm{l}$ ) & 690,67 \\
\hline S9 ( Pemberian MOL dengan konsentrasi $90 \mathrm{ml} / \mathrm{l}$ ) & 668,89 \\
\hline S0 ( tanpa pemberian MOL/Kontrol) & 622,22 \\
\hline
\end{tabular}

Keterangan : Angka-angka yang diikuti huruf yang sama menunjukkan berbeda tidak nyata pada Uji jarak berganda Duncan taraf $5 \%$

Menurut Suripto (2018), Konsentrasi pupuk organik cair sabut kelapa berpengaruh nyata terhadap bobot segar tanaman kentang kleci. Bobot segar merupakan respresentasi dari penimbunan fotosintat dan kandungan air dalam tanaman

\section{Berat Brangkasan kering}

Berdasarkan tabel 1, hasil analisis ragam menunjukkan bahwa pengaruh pengaplikasian mol berpengaruh nyata terhadap variabel pengamatan berat brangkasan kering

Tabel 8. Pengaruh mol sabut kelapa terhadap berat brangkasan kering tanaman mentimun

\section{Perlakuan}

S3 ( Pemberian MOL dengan konsentrasi $30 \mathrm{ml} / \mathrm{l}$ )

S4 ( Pemberian MOL dengan konsentrasi $40 \mathrm{ml} / \mathrm{l}$ )

S2 ( Pemberian MOL dengan konsentrasi $20 \mathrm{ml} / \mathrm{l}$ )

S5 ( Pemberian MOL dengan konsentrasi $50 \mathrm{ml} / \mathrm{l}$ )

S6 ( Pemberian MOL dengan konsentrasi $60 \mathrm{ml} / \mathrm{l}$ )

S7 ( Pemberian MOL dengan konsentrasi $70 \mathrm{ml} / \mathrm{l}$ )

S1 ( Pemberian MOL dengan konsentrasi $10 \mathrm{ml} / \mathrm{l}$ )

S8 ( Pemberian MOL dengan konsentrasi $80 \mathrm{ml} / \mathrm{l}$ )

S9 ( Pemberian MOL dengan konsentrasi $90 \mathrm{ml} / \mathrm{l}$ ) S0 ( tanpa pemberian MOL/Kontrol)
Rata-rata berat berangkasan kering (g)

96,95 a

$91,73 \mathrm{ab}$

89,80 abc

86,71 abcd

81,06 abcd

79,85 abcd

78,68 bcd

77,50 bcd

73,79 cd

$69,60 \mathrm{c}$

Keterangan : Angka-angka yang diikuti huruf yang sama menunjukkan berbeda tidak nyata pada Uji jarak berganda Duncan taraf 5\%

Berdasarkan uji DMRT 5\%, dapat dijelaskan bahwa perlakuan S3 (Pemberian MOL dengan konsentrasi $30 \mathrm{ml} / \mathrm{l}$ ) tidak berbeda nyata dengan variabel perlakuan S4 (Pemberian MOL dengan konsentrasi $40 \mathrm{ml} / \mathrm{l}$ ) tetapi berbeda nyata dengan variabel perlakuan S1 (Pemberian MOL dengan konsentrasi $10 \mathrm{ml} / \mathrm{l}$ ) dan S0 (tanpa pemberian MOL). Perlakuana yang menghasilkan rata-rata 
tertinggi yaitu S3 (Pemberian MOL dengan konsentrasi $30 \mathrm{ml} / \mathrm{l}$ ) dengan berat brangkasan basah 96,95 gram.

Berat brangkasan merupakan salah satu indikator pertumbuhan yang penting karena mempunyai hubungan yang erat dengan hasil tanaman. Berat kering brangkasan merupakan ukuran yang paling sering digunakan untuk menggambarkan dan mempelajari pertumbuhan tanaman, (Johan 2010).

Mol sabut kelapa mengandung bakteri Pseudomonas sp., Citrobacter sp. Yang berfungsi sebagai pelarut fosfat. Pada tanaman jagung, citrbacter intermedium dan pseudomonas putida (Premono at al., 1991) mampu meningkakan serapan P tanaman dan bobot kering tanaman sampai 30\% . pada percobaan yang lain (Butan 1992; Pramono dan widyastuti 1993) pseudomonas Putida mampu meningkatkan bobot kering tanaman jagung sampai 20\% dan mikroba ini stabil sampai lebih dari 4 bulan pada media pembawa ziolit, tanpa kehilangan kemampuan genesisnya dalam melarutkan buatan fosfot.

\section{KESIMPULAN DAN SARAN}

\section{Kesimpulan}

Berdasarkan hasil penelitian Efikasi Mikroorganisme lokal (MOL) dari Sabut Kelapa (Cocos nucifera L.) terhadap Pertumbuhan dan Produksi Tanaman Mentimun (Cucumis sativus L.) dapat disimpulkan bahwa:

1. Efikasi mol sabut kelapa berpengaruh terhadap pertumbuhan tanaman mentimun pada variabel pengamatan Berat Berangkasan Basah Perlakuan dan Berat Berangkasan Kering. Konsentrasi terbaik Pemberian MOL dengan konsentrasi $30 \mathrm{ml} / \mathrm{l}$.

2. Efikasi mol sabut kelapa berpengaruh terhadap produksi tanaman mentimun pada variabel pengamatan jumlah buah pertanaman terbaik 17 buah, berat buah pertanaman terbaik 6747 gram, jumlah buah perplot terbaik 100 buah, berat buah perplot terbaik 40482 gram, dan panjang buah tertinggi 23,66 cm. Konsentrasi terbaik Pemberian MOL dengan konsentrasi $30 \mathrm{ml} / \mathrm{l}$.

\section{Saran}

Efikasi mol sabut kelapa terhadap pertumbuhan dan produksi tanaman mentimun disarankan menggunakan pemberian MOL dengan konsentrasi $30 \mathrm{ml} / \mathrm{l}$. Mengingat kebutuhan unsur hara setiap tanaman berbeda, perlu dilakukan penelitian lebih lanjut pada tanaman lain.

\section{DAFTAR PUSTAKA}

BPS. 2014. Biro Pusat Statistik Konsumsi Pangan. Biro Pusat Statistik.

Buntan, A. 1992. Efektifitas bakteri pelarut fosfat dalam kompos terhadap peningkatan serapan $\mathrm{P}$ dan efisiensi pemupukan $\mathrm{P}$ pada tanaman jagung. Tesis. Program Pascasarjana IPB. Bogor. 
Cahyono, B. (2003). Timun. Aneka Ilmu. Semarang.

Firdausi, N., \& Muslihatin, W. (2016). Pengaruh Kombinasi Media Pembawa Pupuk Hayati Bakteri Pelarut Fosfat Tehadap pH dan Unsur Hara Fosfor dalam Tanah. Jurnal Sains dan Seni ITS, 5(2).

Galla, E. A. (2018). Respon pertumbuhan dan produksi tanaman cabai (capsiicum annum) varietas lokal toraja terhadap pupuk organik cair sabut kelapa. AgroSainT, 9(1), 7-15.

Gardner, F. P., Pearce, R. B., \& Mitchell, R. L. (1991). Fisiologi Tanaman Budidaya(Physiology of Crop Plants). Ul-Press. Jakarta.

Hanafiah, K.A. 2005. Dasar-Dasar Ilmu Tanah. Jakarta (ID) : Raja Grafindo Persada.

Handayani Sri Hesti, Ahmad Yunus, dan Ari Susilowati. 2015. Uji kualitas pupuk organic cair dari berbagai macam mikroorganisme local (MOL). EL-VIVO, Vol.3, No.1; 54-60

Jamilah, Yopi Napitupulu dan Yunis Marni. 2013. Peranan Gulma Chromoleana odorata dan Sabut Kelapa sebagai Bahan Baku Pupuk Organik Cair Menggantikan Pupuk Kalium untuk Pertumbuhan dan Hasil Padi Ladang. Padang: Fakultas Pertanian Universitas Taman Siswa Padang.

Johan Sasongko. 2010. Pengaruh Macam Pupuk Npk Dan Macam Varietas Terhadap Pertumbuhan Dan Hasil Tanaman Terong Ungu (Solanum Melongena L.). Skripsi. Program Studi Agronomi. Fakultas Pertanian. Universitas Sebelas Maret. Surakarta.

Martias, Nasution F, Noflindawati, Budiyanti, T. dan Hilman. Y 2011. Respon pertumbuhan dan produksi papaya terhadap pemupukan nitrogen dan kalium dilahan rawa pasang surut.

Norhasanah. 2011 Respon Pertumbuhan Dan Hasil Tanaman Cabe Rawit (Capsicum frutescens linn.) Varietas cakra hijau Terhadap Pemberian Abu Sekam Padi Pada Tanah Rawa Lebak. Program Studi Agroteknologi Sekolah Tinggi Pertanian STIPER . Amuntai Hulu Sungai Utara.

Nursanti, I. (2017). Teknologi Produksi Dan Aplikasi Mikroba Pelarut Hara Sebagai Pupuk Hayati. Jurnal Media Pertanian, 2(1), 24-36.

Premono, E.M., R. Widyastuti dan I. Anas. 1991. Penagruh bakteri pelarut fosfat terhadap senyawa $\mathrm{P}$ sukar larut, ketersediaan $\mathrm{P}$ tanah dan pertumbuhan jagung pada tanah masam. Makalah PIT Permi. 2-3 Desember 1991. Bogor.

Premono, E.M dan R. Widyastuti. 1993. Stabilitas Pseudomonas putida dalam beberapa bahan pembawa dan peranannya sebagai pupuk hayati. Kongres nasional IV Perhimpunan Mikrobiologi Indonesian. 2-4 Desember 1993. Surabaya.

Purwasasmita, M., \&Kunia, K. (2009, October). Mikroorganisme local sebagai pemicu siklus kehidupan dalam bioreactor tanaman. In Seminar Nasional Teknik Kimia Indonesia (pp. 19-20). 
Agritrop, Vol. 17 (2): 163 - 176

Rahni, N. M. (2012). Efek Fitohormon PGPR terhadap pertumbuhan tanaman jagung (Zea mays). CEFARS: Jurnal Agribisnis dan Pengembangan Wilayah, 3(2), 2735 .

Rusmana, N. dan A.A. Salim. 2003. Pengaruh kombinasi pupuk daun puder dan takaran pupuk N, P, K yang berbeda terhadap hasil pucuk tanaman teh (Camelia sinensis (L) O. Kuntze) seedling, TRI 2025 dan GMB 4. Jurnal Penelitian Teh dan Kina. Bandung. 9 (1-2): 28-39.

Sumpena, U. 2005. Budidaya Mentimun Intensif. Penebar Swadaya. Jakarta

Suripto, W., Purwani, T., \& Nugroho, B. (2018, May). Pengaruh Konsentrasi Pupuk Organik Cair Sabut Kelapa Terhadap Pertumbuhan dan Hasil Kentang Kleci. In Prosiding Seminar Nasional Fakultas Pertanian UNS (Vol. 2, No. 1, pp. A220). 